\title{
Phorbol ester degradation in Jatropha seedcake using white rot fungi
}

\author{
Anjali Bose $\cdot$ Haresh Keharia
}

Received: 12 June 2013/Accepted: 15 September 2013/Published online: 26 September 2013

(C) The Author(s) 2013. This article is published with open access at Springerlink.com

\begin{abstract}
White rot fungi are well known for their ability to degrade a wide range of xenobiotics due to their enzymatic systems. Therefore, the present investigation was aimed at screening ten different white rot fungi for degradation of phorbol esters from Jatropha seedcake (JSC). The JSC was fermented with pure cultures of white rot fungi for 20 days under solid state condition. All the white rot fungi tested exhibited degradation of phorbol ester during fermentation of JSC without adversely influencing the nutritional properties of the seedcake. Ganoderma lucidum and Trametes zonata were found to degrade phorbol ester in JSC to undetectable levels. This study demonstrates the potential of white rot fungi for degradation of phorbol esters, a major anti-nutritional factor, in JSC preventing its utilization as cattle feed.
\end{abstract}

Keywords Jatropha seedcake - White rot fungi .

Phorbol ester

The bio-diesel production from Jatropha curcas L. gained momentum due to its inedible oil content that can be converted to fuel without competing with the food market. The extraction of oil from Jatropha seeds is associated with generation of substantial amount of seedcake waste at an average rate of $500 \mathrm{~g}$ cake per $\mathrm{kg}$ of seeds used (Zanzi et al. 2008). Inspite of its high protein content along with

Electronic supplementary material The online version of this article (doi:10.1007/s13205-013-0174-9) contains supplementary material, which is available to authorized users.

A. Bose $\cdot$ H. Keharia $(\square)$

BRD School of Biosciences, Sardar Patel Maidan, Sardar Patel

University, Satellite Campus, Vadtal Road, P.O. Box 39,

Vallabh Vidyanagar 388 120, Gujarat, India

e-mail: haresh970@gmail.com presence of all essential amino acids, except lysine (Makkar and Becker 1997b), it cannot be used in feed formulation due to the presence of potential anti-nutritional components like phorbol esters (PE), lectins and trypsin inhibitors (Makkar et al. 1997). The PEs, have been identified as main toxicants in JSC, which could not be destroyed even by heating at $160{ }^{\circ} \mathrm{C}$ for $30 \mathrm{~min}$ (Makkar et al. 1998) and, therefore, its removal is currently an important issue to be addressed. Several physico-chemical methods have been developed for PE removal, but none has proved to be economically feasible (Aregheore et al. 2003; Martínez-Herrera et al. 2006; Rakshit et al. 2008).

In this context, use of JSC as substrates for microbial fermentation would not only add to its utility, but during the process of fermentation there exists a possibility of degradation of anti-nutritional factors present in it, thereby solving its subsequent disposal issues. The feasibility of this approach has been demonstrated for reducing gossypol in cotton seed meal using Geotrichum candidum (Sun et al. 2008) and ricin in castor seedcake by Paecilomyces variotii (Madeira et al. 2011).

As white rot fungi are well known for their ability to degrade a wide range of xenobiotics, such as polyphenolic compounds and synthetic dyes, due to the secretion of extracellular enzymes (Asgher et al. 2008; Alberts et al. 2009), the present study was undertaken to investigate the ability of ten different white rot fungi, namely, Ganoderma lucidum (GL), Pleurotus florida (PF), Pleurotus sapidus (PS), Pleurotus sajor-caju (PSC), Pleurotus ostreatus (PO), Phanerochaete chrysosporium (PC), Trametes hirsute (TH), Trametes zonata (TZ), Trametes gibbosa (TG) and Trametes versicolor (TV) for degradation of PE in deoiled JSC. They were grown on $2 \%(\mathrm{w} / \mathrm{v})$ malt extract agar plates at $27{ }^{\circ} \mathrm{C}$, preserved at $4{ }^{\circ} \mathrm{C}$ on malt extract agar slopes and maintained by subculturing once in 2 months. 
Twenty-five grams of JSC (obtained from Food Processing and Bioenergy division, Anand Agriculture University, Gujarat) was taken in 250-mL Erlenmeyer flask, moistened with $30 \mathrm{~mL}$ of distilled water and autoclaved. The flasks were inoculated with two blocks $(1 \mathrm{~cm} \times 1 \mathrm{~cm})$ of actively growing individual fungal culture, followed by incubation at $30{ }^{\circ} \mathrm{C}$ and $70 \%$ relative humidity. An uninoculated flask served as experimental control. After 20 days of fermentation, the content of the flasks were extracted and analyzed for PE and nutrients. All the experiments were done in triplicates.

Phorbol esters were extracted by following the method described by Joshi et al. (2011) and quantified using C-18 reverse-phase HPLC employing a Luna 18 column $(250 \times 4.6 \mathrm{~mm}$, octadecyl group, particle size $5 \mu \mathrm{m})$ procured from Phenomenex (USA). The separation was carried out with the solvent system: water and acetonitrile (40\% acetonitrile for $15 \mathrm{~min}$ followed by gradient of $40-75 \%$ acetonitrile for $20 \mathrm{~min}$ and then to $100 \%$ acetonitrile for $5 \mathrm{~min}$ and finally returned to $40 \%$ for the next $5 \mathrm{~min}$ ) with a flow rate $1.3 \mathrm{~mL} / \mathrm{min}$ at $25{ }^{\circ} \mathrm{C}$. The detector (Photo Diode Array) wavelength was set on $280 \mathrm{~nm}$ and 5 $\mu \mathrm{L}$ of sample was injected for analysis.

Normally, Jatropha sp. is reported to have four to six PEs or its derivatives (Haas et al. 2002; Barros et al. 2011), out of which, phorbol-12-myristate 13-acetate (PMA) is the major PE in J. curcas (Makkar and Becker 1997a). However, we observed three major peaks at 25.1, 25.26 and $25.6 \mathrm{~min}$ (Fig. 1a), which appeared at a lower retention time as compared to external standard PMA (Sigma Chemical Co., USA) dissolved in absolute methanol that appeared at $33.09 \mathrm{~min}$. The type and quantity of individual PEs in Jatropha seed depends on the genotype of plant and the prevailing soil/climatic conditions (Martínez-Herrera et al. 2006). Makkar et al. (1997) reported varying concentration of PE from 0.8 to $3.3 \mathrm{mg} / \mathrm{g}$ in $J$. curcas kernel meal from different geographical sites. Ahmed and Salimon (2009) analyzed three different varieties of tropical $J$. curcas from Malaysia, Indonesia and India and observed two, five and four PE peaks, respectively.

The fermentation of JSC with edible white rot fungi lowered PEs content from $1.072 \mathrm{mg} / \mathrm{g}$ in unfermented control up to undetectable level in fermented seedcake (Fig. 1 and supplementary figure). The degradation of PE was observed by all the white rot fungi tested but the extent of degradation varied with the fungal culture (Fig. 1b). G. lucidum and $T$. zonata were found to completely degrade PEs in JSC. Trace amounts of PEs could be detected in JSC upon fermentation by $T$. versicolor and T. gibbosa, whereas Pleurotus sp. degraded $\sim 70 \%$ of initial PE present. However, Ph. chrysosporium could only reduce PE content up to $\sim 45 \%$. The extent of reduction in PE content by $G$. lucidum, T. zonata, T. versicolor and T. gibbosa was
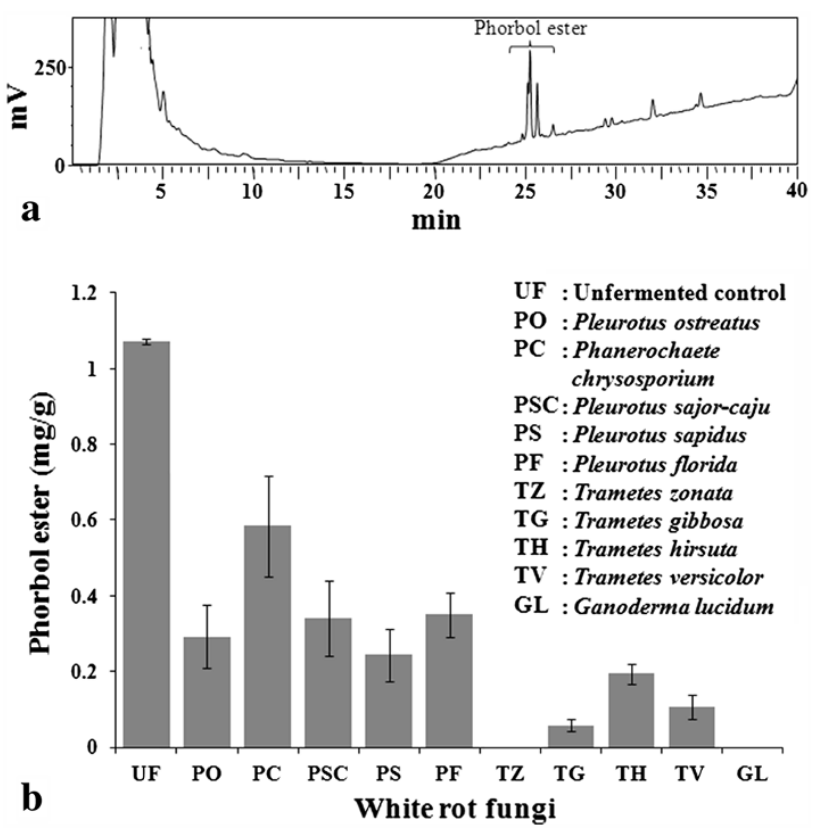

Fig. 1 a HPLC chromatogram of phorbol esters from unfermented Jatropha seedcake and $\mathbf{b}$ Effect of fungal treatment on phorbol ester concentrations

comparable to the reports by Barros et al. (2011) and Belewu and Sam (2010).

Further the nutritive value was evaluated using the protocols of Indrayan et al. (2005) with few modifications. The analysis involved the determination of moisture content by drying samples at $105{ }^{\circ} \mathrm{C}$ to constant weight. Ash content and the total organic matter were estimated by determining the loss in weight after igniting the samples in a muffle furnace at $550{ }^{\circ} \mathrm{C}$ for $12 \mathrm{~h}$. Dry fermented seedcake was digested using concentrated $\mathrm{H}_{2} \mathrm{SO}_{4}$ followed by distillation with $\mathrm{NaOH}$ in Kel Plus Nitrogen estimation system (Classic DX, Pelican Equipments) prior to determination of total nitrogen. Total nitrogen was estimated through titration of the distillate collected from the Kel Plus distillation unit against $0.1(\mathrm{~N}) \mathrm{H}_{2} \mathrm{SO}_{4}$. The total protein content was determined by multiplying total Kjeldahl nitrogen with 6.25. Total fat was determined by extracting $2 \mathrm{~g}$ sample with hexane in a Soxhlet extractor for $6 \mathrm{~h}$. The hexane extract was then evaporated and residue left was weighed to determine total fat. The total carbohydrate and nutritive value was then calculated using following equations:

Carbohydrate (\%) was given by: 100

$-($ Ash $\%+$ Fat $\%+$ Protein $\%)$.

Nutritive value was determined by: $4 \times$ Protein $\%+9$

$\times$ Fat $\%+4 \times$ Carbohydrate $\%$.

To determine total $P$ and $K$, the samples were first digested with a mixture of nitric acid and perchloric acid 
Table 1 Nutritive composition of unfermented (control) and fermented Jatropha seedcake

\begin{tabular}{lllllllll}
\hline Treatments & Protein $(\%)$ & Fat $(\%)$ & Ash $(\%)$ & $P(\mathrm{ppm})$ & $K(\mathrm{ppm})$ & Moisture $(\%)$ & Carbohydrate $(\%)$ & Nutritive value \\
\hline UF & $23.33 \pm 0.48$ & 0.65 & $5.83 \pm 0.17$ & 56 & 3,250 & $58.3 \pm 0.28$ & 11.99 & 146.73 \\
PO & $25.92 \pm 0.06$ & 0.7 & $7.55 \pm 0.16$ & 189 & 4,830 & $55.7 \pm 0.41$ & 10.13 & 150.5 \\
PC & $25.26 \pm 0.25$ & 0.65 & $7.89 \pm 0.31$ & 175 & 6,350 & $51.57 \pm 0.22$ & 14.63 & 165.41 \\
PSC & $26.44 \pm 0.3$ & 0.7 & $7.64 \pm 0.18$ & 168 & 6,650 & $53.95 \pm 0.48$ & 11.27 & 1 \\
PS & $30.15 \pm 0.39$ & 0.65 & $7.47 \pm 0.01$ & 189 & 6,750 & $54.73 \pm 0.75$ & 7 & 157.14 \\
PF & $25.33 \pm 0.25$ & 0.7 & $7.63 \pm 0.58$ & 189 & 4,730 & $53.45 \pm 0.15$ & 12.89 & 159.18 \\
TZ & $27.33 \pm 0.12$ & 0.6 & $6.98 \pm 0.3$ & 182 & 6,300 & $56.65 \pm 0.19$ & 8.44 & 148.48 \\
TG & $28.05 \pm 0.15$ & 0.5 & $7.43 \pm 0$ & 161 & 5,230 & $55.48 \pm 0.31$ & 8.54 & 150.86 \\
TH & $29.46 \pm 0.63$ & 0.55 & $7.28 \pm 0.16$ & 175 & 2,550 & $53.64 \pm 0.43$ & 9.07 & 159.07 \\
TV & $29.39 \pm 0.07$ & 0.55 & $7.74 \pm 0.2$ & 175 & 5,830 & $52.44 \pm 0.72$ & 9.88 & 162.03 \\
GL & $28.07 \pm 0.12$ & 0.5 & $8.24 \pm 0.18$ & 175 & 6,680 & $54.86 \pm 0.05$ & 8.33 & 150.1 \\
\hline
\end{tabular}

UF unfermented Jatropha seedcake as experimental control, PO Pleurotus ostreatus, PC Phanerochaete chrysosporium, PSC Pleurotus sajorcaju, PS Pleurotus sapidus, PF Pleurotus florida, TZ Trametes zonata, TG Trametes gibbosa, TH Trametes hirsuta, TV Trametes versicolor and GL Ganoderma lucidum fermented Jatropha seedcake

(9:4). Phosphorus in the digestate was estimated through formation of vanado-molybdo-phosphoric-heteropoly complex followed by absorbance measurement at $420 \mathrm{~nm}$ (Gupta 2004). The potassium was measured in the digestate using flame photometer (Singh et al. 2007).

The results of proximate composition of fungal fermented and unfermented JSC (Table 1) exhibited slight increase in protein content (2.03-6.92\%). The increment in the protein content could be due to the addition of microbial protein during the process of fermentation. Ash content was found to increase significantly in JSC upon fermentation by all the white rot fungi tested. The increase in ash content of fermented seedcake may be considered as an indicator of mineralization (Table 1). Similar observation regarding increase in ash content has been reported for cotton waste upon fermentation by Volvariella volvacea (Akinyele and Akinyosoye 2005). Further, the fat content remained almost unchanged in most of the treatments, however, 4-9\% decrease in carbohydrate content was observed. Such decrease in carbohydrate content may be attributed to its utilization as nutrient source during fungal colonization. In present study, the overall nutritive value of the fermented seedcake remained almost unchanged. However, increase in nutritive value of agrowastes upon fermentation by fungi has been reported by Akinyele and Akinyosoye (2005).

Thus, the present investigation clearly demonstrated that solid state fermentation of JSC by white rot fungi could totally remove PE content and could be applied for large scale detoxification. Apart from this, the fermented seedcake would then retain high protein content and other nutritional values applicable to the animal feed industry.

Acknowledgments A. Bose acknowledges the University Grants Commission, New Delhi for financial support in form of meritorious fellowship. Authors thank Central Salts and Mineral Chemicals Research Institute, Bhavnagar for providing the analytical facility toward HPLC analysis.

Conflict of interest The authors declare that they have no conflict of interest.

Open Access This article is distributed under the terms of the Creative Commons Attribution License which permits any use, distribution, and reproduction in any medium, provided the original author(s) and the source are credited.

\section{References}

Ahmed WA, Salimon J (2009) Phorbol esters as constituents of tropical Jatropha curcas seed oil. Eur J Sci Res 31:429-436

Akinyele BJ, Akinyosoye FA (2005) Effect of Volvariella volvacea cultivation on chemical composition of agrowastes. Afr J Biotechnol 4:979-983

Alberts JF, Gelderblom WCA, Botha A, van Zyl WH (2009) Degradation of aflatoxin B1 by fungal laccase enzymes. Int $\mathrm{J}$ Food Microbiol 135:47-52

Aregheore EM, Becker K, Makkar HPS (2003) Detoxification of a toxic variety of Jatropha curcas using heat and chemical treatments, and preliminary nutritional evaluation with rats. S Pac J Nat Sci 21:50-56

Asgher M, Bhatti HN, Ashraf M, Legge RL (2008) Recent developments in biodegradation of industrial pollutants by white rot fungi and their enzyme system. Biodegradation 19:771-783

Barros CRM, Ferreira LMM, Nunes FM, Bezerra RFM, Dias AA, Guedes CV, Cone JW, Marques GSM, Rodrigues MAM (2011) The potential of white-rot fungi to degrade phorbol esters of Jatropha curcas L. seed cake. Eng Life Sci 11:107-110

Belewu MA, Sam R (2010) Solid state fermentation of Jatropha curcas kernel cake: proximate composition and antinutritional components. J Yeast Fungal Res 1:44-46

Gupta PK (2004) Soil, plant, water and fertilizer analysis. Agrobios, India

Haas W, Sterk H, Mittelbach M (2002) Novel 12-deoxy-16hydroxyphorbol diesters isolated from the seed oil of Jatropha curcas. J Nat Prod 65:1334-1440 
Indrayan AK, Sharma S, Durgapal D, Kumar N, Kumar M (2005) Determination of nutritive value and analysis of mineral elements for some medicinally valued plants from Uttaranchal. Current Sci 89:1252-1255

Joshi C, Mathur P, Khare SK (2011) Degradation of phorbol esters by Pseudomonas aeruginosa PseA during solid-state fermentation of deoiled Jatropha curcas seed cake. Bioresour Technol 102:4815-4819

Madeira JV Jr, Macedo JA, Macedo GA (2011) Detoxification of castor bean residues and the simultaneous production of tannase and phytase by solid-state fermentation using Paecilomyces variotii. Bioresour Technol 102:7343-7348

Makkar HPS, Becker K (1997a) Jatropha curcas toxicity: identification of toxic principles. In: Proceedings of the 5th international symposium on poisonous plants. San Angelo, 19-23 May

Makkar HPS, Becker K (1997b) Potential of Jatropha seedcake as a protein supplement in livestock feed and constraints to its utilization. In: Proceedings of the Jatropha 97: international symposium on biofuel and industrial products from Jatropha curcas and other tropical oil seed plants. Managua, Nicaragua, 23-27 February

Makkar HPS, Becker K, Sporer F, Wink M (1997) Studies on nutritive potential and toxic constituents of different provenances of Jatropha curcas. J Agric Food Chem 45:3152-3157
Makkar HPS, Aderibigbe AO, Becker K (1998) Comparative evaluation of nontoxic and toxic varieties of Jatropha curcas for chemical composition, digestibility, protein degradability and toxic factors. Food Chem 62:207-215

Martínez-Herrera J, Siddhuraju P, Francis G, Dávila-Ortíz G, Becker K (2006) Chemical composition, toxic/antimetabolic constituents, and effects of different treatments on their levels, in four provenances of Jatropha curcas L. from Mexico. Food Chem 96:80-89

Rakshit KD, Darukeshwara J, Raj KR, Narasimhamurthy K, Saibaba P, Bhagya S (2008) Toxicity studies of detoxified Jatropha meal (Jatropha curcas) in rats. Food Chem Toxicol 46:3621-3625

Singh D, Chhonkar PK, Dwivedi BS (2007) Manual on soil, plant and water analysis. Westville Publishing House, New Delhi

Sun ZT, Liu C, Du JH (2008) Optimisation of fermentation medium for the detoxification of free gossypol in cottonseed powder by Geotrichum candidum G07 in solid-state fermentation with response surface methodology. Ann Microbiol 58:683-690

Zanzi R, Perez JAS, Soler PB (2008) Production of biodiesel from Jatropha curcas in the region of Guantanamo in Cuba. In: Proceedings of the 3 rd international congress university-industry cooperation, Ubatuba, Brazil 